\title{
Genetic variation among Dengue Virus that possibly correlate with pathogenesis
}

\author{
Muhareva Raekiansyah", T Mirawati Sudiro ${ }^{f}$
}

\begin{abstract}
Abstrak
Penyakit dengue masih merupakan masalah kesehatan penting di sebagian besar Negara tropis dan subtropis. Dalam dua dekade terakhir terjadi lonjakan drastis baik jumlah kasus maupun daerah endemik di samping peningkatan keparahan penyakit (DHF/DSS). Meski telah dipelajari secara intensif, belum dipahami benar bagaimana mekanisme infeksi dengue berkembang menjadi DHF/DSS. Sejauh ini diketahui baik faktor inang maupun virulensi virus terlibat dalam menentukan keparahan penyakit. Studi-studi terbaru melaporkan perbedaan struktural genom di antara virus dengue yang memberikan manifestasi klinis berbeda. Perbedaan ini kemungkinan berhubungan dengan patogenesis penyakit. (Med J Indones 2004; 13: 190-4)
\end{abstract}

\begin{abstract}
Dengue disease are reemerging disease and major health concern in tropical and subtropical regions because of the increasing number of patients, expanding endemic areas and increased occurrence of severe clinical manifestation (DHF/DSS) in the last two decades. Despite extensive studies, it is not fully elucidated mechanism by which dengue infection progress to DHF/DSS. Information obtained so far indicates that both host-related factor and virus virulence are involved. Recent studies have shown several structural differences of dengue virus genome between those associated with DF only and those with the potential to cause DHF. That genome differences might be correlated with pathogenesis. (Med J Indones 2004; 13: 190-4)
\end{abstract}

Keywords: dengue virus, virulence factor, pathogenesis

Dengue virus belong to the genus Flavivirus of the family Flaviviridae. It consists of four distinct antigenic type (DEN-1 to DEN-4). The virus is transmitted to human, principally by Aedes aegypti or Aedes albopictus mosquito. While most dengue virus infection are present as asymptomatic or mild, self-limited dengue fever (DF), some patients may develop severe and potentially life-threatening dengue hemorrhagic fever (DHF) characterized by capillary leakage and thrombocytopenia. In the most extreme cases, patients may develop hypovolemic shock (dengue-shock syndrome/DSS) with a 5-10\% case fatality rate. ${ }^{1}$

Recently, DF/DHF has emerged as the most important viral that affecting nearly half of the world's population. Epidemic of the four dengue virus continue to be a

\footnotetext{
* Program of Biomedical Science, Faculty of Medicine, University of Indonesia, Jakarta, Indonesia

$f$ Department of Microbiology, Faculty of Medicine, University of Indonesia, Jakarta, Indonesia
}

major public health problem in over 100 tropical and sub-tropical countries with 2 billion people at risk. It has been estimated that approximately 100 million cases of DF and 500.000 cases of DHF occur annually worldwide. During the last two decade, DHF has become the leading cause of death and hospitalization among children in Southeast Asian countries. ${ }^{1}$

Despite extensive studies, the pathogenesis of DHF is still not fully understood. The lack of in vivo and in vitro models of severe dengue disease have hampered the identification of mechanism by which dengue infection progress to DHF. However, it has been shown by epidemiologic and clinical association that both immunologic and viral factor determine the severity of disease. Other risk factors in promoting DHF have also been postulated such as a genetic predisposition among certain population, age, sex, and nutritional status. $^{2}$

In this paper, we present a brief review of models of pathogenesis in DHF and the genetic variations 
among dengue virus that probably responsible for the severe disease of dengue. Recent studies have been shown that several structural differences in viral genome could correlate with the pathogenesis of DHF. $3,4,5$

\section{Pathogenesis}

The precise mechanism(s) by which dengue virus cause severe DHF/DSS has not fully elucidated. So far, it is still uncertain what kind of host and virusspecified factors determine why a certain individual develops life-threatening infection while others recover without consequences or experience only mild DF. However, a number of models have been proposed for pathogenesis of DHF, based on epidemiologic and experiment data.

One proposed hypothesis is antibody-dependent enhancement (ADE). This controversial hypothesis arose from the observation that secondary infection with a heterotypic dengue virus is associated with an increased risk of developing DHF and experiment demonstrating that sub-neutralizing concentration of antibodies can increased virus titer in primates and in vitro. ${ }^{6} \mathrm{ADE}$ of dengue virus infection has been demonstrated to occur via Fc $\gamma$ receptor on monocyte cells that bind to virus-immunoglobulin G-complexes. That binding direct the virus to the cell surface, thereby increasing the probability of interaction between dengue virus and its viral receptor and facilitate virus entry. ${ }^{7}$ However, enhancing antibody hypothesis is not supported by clinical data. Clinical studies has shown that viral titers are no higher or possible lower in patients with DHF compared with to those with DF, or patient with secondary dengue infection compared to with those with primary infection. ${ }^{8}$

Furthermore, the role of host immune factors has been examined in a number of studies. ADE has implicated in self-amplifying cascade of activation of preexisting cross-reactive dengue virus-specific $\mathrm{T}$ lymphocytes from primary infection. This cascade can than lead to the release of different cytokines, interferon, and abnormalities in coagulation which may increased capillary permeability, the hallmark of DHF (Figure 1). ${ }^{9,10}$

\section{Viral Factor}

Recent reports have indicated that viral factors are also involved in pathogenicity. It has been shown that strains of dengue virus may differ in their ability to infect cell and to cause disease. ${ }^{5,11,12}$ In some area of the world, secondary infection by some DEN-2 do not produce severe disease, in contrast to the aforementioned ADE model. ${ }^{13}$

In general, epidemiological analysis of dengue epidemic reveals that some dengue virus strains are associated with mild epidemics with low occurrence of DHF and inefficient virus transmission, whereas others are involved in severe epidemic with high incidence of DHF/DSS and rapid virus transmission. ${ }^{15}$ The first case of DHF in the Americas, for example, were reported in Cuba in 1981, and this coincided with the introduction of the Southeast (SE) Asia genotype of DEN-2 into this hemisphere. Since then, other countries in the Americas have reported DHF associated with DEN-2 viruses of the SE Asian genotype and not indigenous American genotype. ${ }^{12}$ Similarly, outbreaks of DHF in some Pacific Islands have been traced to the introduction of SE Asian dengue strains. ${ }^{16}$ In Malaysia, introduction of DEN-3 viruses from Thailand was directly associated with the DHF epidemic in 1993-1994. ${ }^{17}$

Current study using phylogenetic approach in Sri Lanka have been confirmed the establishment of a new genotypes of DEN-3, subtype III variant that correlate with the recent emergence of DHF. It indicates that endemic virus had undergone some genetic drift. ${ }^{3}$ In SE Asia (Indonesia and Thailand) historically, DEN-2 and DEN-3 have been more commonly associated with DSS over two decade that have DEN-1 and DEN-4. ${ }^{15}$ This data suggest that a specific genotype or type of dengue virus may have propensity to cause DHF, where others are only associated with the less severe DF and the genetic evolution of the virus within each type has resulted generation of more virulent or epidemic strains of dengue viruses.

\section{Genome and Genetic Diversity}

As with other flavivirus, the genome of dengue virus consists of a single stranded RNA about 11 kilobases $(\mathrm{kb})$ in length, surrounded by a nucleocapsid and covered by a lipid envelope containing the envelope and the membrane protein. Genomic RNA messenger RNA for translation for a single long open reading frame (ORF) as a large precursor polyprotein. Flanking the ORF are two nontranslated regions (5' and 3' NTR) of around 100 nucleotides (nt) and 400 
to $700 \mathrm{nt}$, respectively. Co- and posttranslational proteolitic cleavage of the precursor result in the formation of three structural protein, capsid (C), membrane (M), and envelope (E), and seven nonstructural protein, NS1, NS2a, NS2b, NS3, NS4a, NS4b, and NS5 (Figure 2). ${ }^{18}$

Nucleotide sequencing of the entire E gene has been used as a tool for study of molecular epidemiology for determining the origin and spread of dengue virus. Within each of the four dengue virus types, phylogenetic studies have identified genetic subtype that differ in nucleotide sequence up to $12 \%$ in envelop of that gene. ${ }^{19}$ So far, the phylogentic study of the $\mathrm{E}$ gene permit classification of each dengue type into a number of E-genotypes that correlate with geographic origin. DEN-1 comprises five known subtype, 1-V and DEN-2 comprises six, although DEN-2 subtype II has been further divided into sublineages, IIIa and IIIb. ${ }^{19}$ DEN-3 and DEN-4 viruses currently are classed into four and two different subtypes respectively. However, the current classification will expand as more strains of each dengue type being examined. Within a single geographic area, genetic change in the virus population may be found over time, with the appearance of new variants by mutation and selection as well as by introduction from afar. ${ }^{20}$

\section{Genome Differences That Correlate with Pathogenesis}

Many study of wild and attenuated dengue viruses have identified genetic differences among strains of four type that associated with attenuation, virulence, and/or epidemic potential. Although a various numbers of nucleotide and amino acid differences were found throughout the RNA genome in both protein coding and nontranslated region (NTR's), most of the molecular markers have been localized in the E gene. Despite of the fact, no specific site(s) could be correlated with attenuation or severe disease in human. In vitro (e.g., plaque size) and in vivo (e.g., mouse neurovirulence and monkey viremia) markers used to pinpoint probable virulence determinants have been shown to be imperfect models of human disease. ${ }^{5}$ However, potential genetic determinants of dengue virulence have been studied by sequencing the entire genome of dengue virus isolated from patients exhibiting different disease severities. ${ }^{4,5,21}$

It has been reported several structural differences that were seen consistently between the two DEN-2 genotype that have been associated with distinct clinical presentation in human: the Southeast Asian genotype with DF and DHF and the American genotype with DF only. A total of six encoded amino acid change differences were seen in the premembrane protein (prM; amino acid $28 \mathrm{Glu} \rightarrow$ Lys), the envelope glycoprotein (E; amino acid 390 Asn $\rightarrow$ Asp), the nonstructural protein $4 \mathrm{~b}$ (NS4b; amino acid 17 Ser $\rightarrow$ His), and NS5 (amino acid 645 Asn $\rightarrow$ Asp, 676 Ser $\rightarrow$ Arg), and 800 Lys $\rightarrow$ Ser), while sequences differences observed within the 5' nontranslated region (NTR) and 3'NTR were predicted to alter RNA secondary structures of both ends genome. They has suggested that the primary determinant of DHF reside in (i) amino acid 390 of the $E$ protein, which purportedly alters virion binding to host cells; (ii) in the downstream loop (nt 68-80) of the 5'NTR, which may be involved in translation initiation; and (iii) in the upstream 300 nucleotide of the 3'NTR, which may regulate viral replication via the formation of replicative intermediates. However, the significance of four amino acid differences in the nonstructural protein NS4b and NS5, a presumed transport protein and the viral RNA polymerase, respectively, remain unknown. ${ }^{5}$

Recent study reported the insertion of both 5'- and 3'terminal American genotype sequences into SE Asian-derived infectious clone (chimera) that alter the efficiency of replication of the clone. It indicates that American genotype structures decreased the replicative ability of an SE Asia-derived infectious clone and may provide part of the explanation of why the American genotype dengue viruses are not associated with the occurrence of DHF. ${ }^{22}$

Furthermore, the comparative study among the Thai and The American strains found a possible correlation between the amino acid sequence subtype of virus strains of DEN-2 and clinical severity and serological response of the patients from whom each virus strain was isolated. Three amino acid replacements were characteristic to a single subtype I virus strain isolated from a DSS case: $\mathrm{D} \rightarrow \mathrm{G}$ change at position 278 in $\mathrm{NS} 1 ; \mathrm{N} \rightarrow \mathrm{D}$ change at 139 in NS2a; $\mathrm{M} \rightarrow \mathrm{I}$ change at 13 in NS3. Five different amino acid replacements were characteristic to subtype III virus strains, all isolated from DF cases: $\mathrm{I} \rightarrow \mathrm{R}$ change at 16 and $\mathrm{T} \rightarrow \mathrm{A}$ at 81 in $\mathrm{prM} ; \mathrm{I} \rightarrow \mathrm{M}$ at 136 in NS2A; $\mathrm{A} \rightarrow \mathrm{T}$ at 118 in $\mathrm{NS} 3$; and $\mathrm{T} \rightarrow \mathrm{M}$ at 337 in $\mathrm{NS} 5 .^{4}$ Some of these replacements have been described in several studies. ${ }^{23,24}$ 


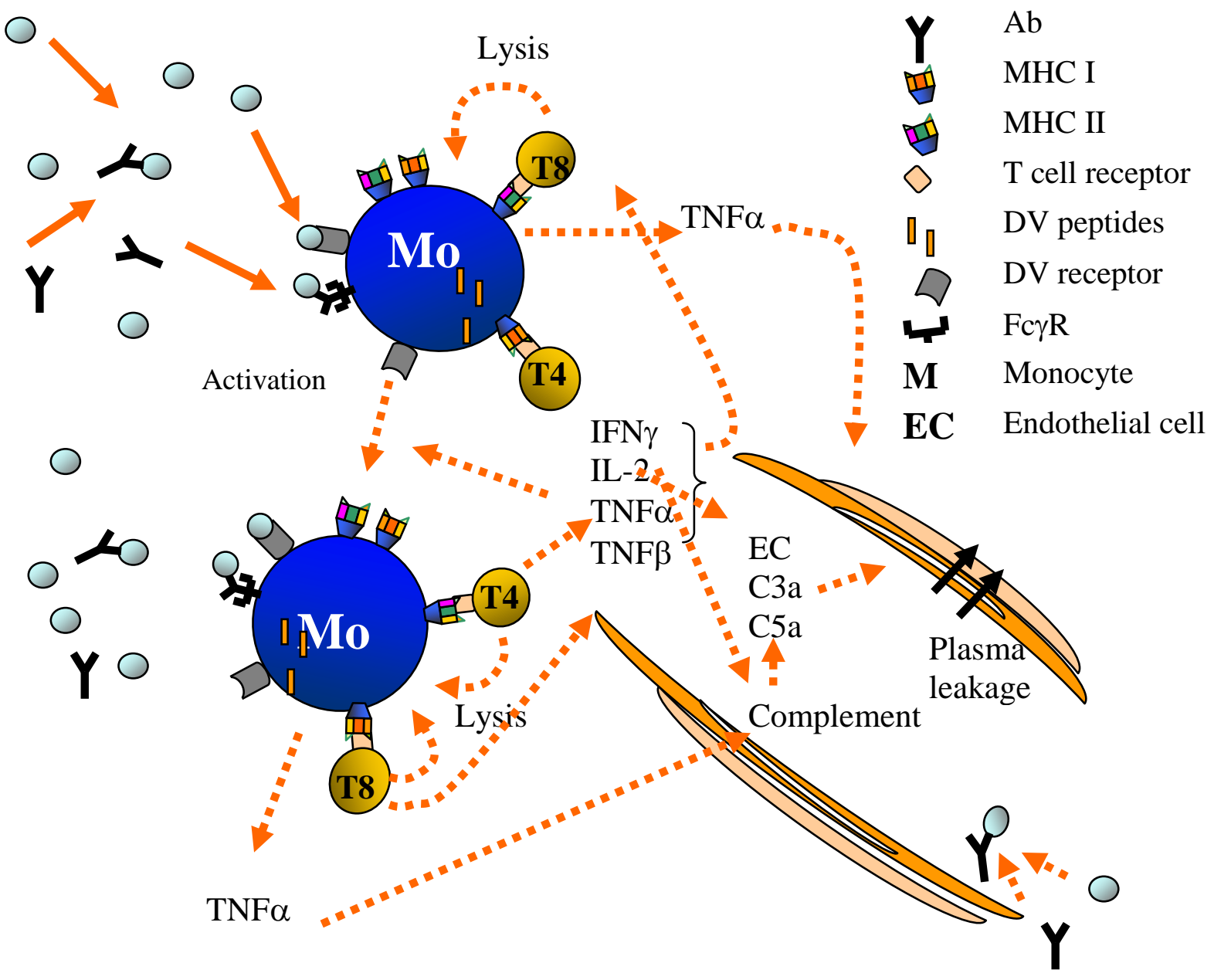

Figure 1. Models of immunopathogenesis of plasma leakage in dengue hemorrhagic fever (DHF). Serotype cross-reactive antibodies $(A b)$, present at the time of secondary dengue virus $(D V)$ infection, bind to virion without neutralization and then enhance the entry of virus into monocytic cell $(\mathrm{Mo})$ expressing immunoglobulin receptors $(F \mathrm{c} \gamma \mathrm{R})$ (upper left). Subtype cross-reactive memory CD4+ and CD8+ T lymphocytes recognized viral antigens in the context of class I and Class II HLA molecules. These T lymphocytes produced cytokine such as interferon- $\gamma(I F N-\gamma)$, interleukin-2 (IL-2), and tumor necrosis factors $\alpha$ and $\beta$ (TNF- $\alpha$ and TNF- $\beta)$ and lyses dengue virus-infected monocytes. TNF- $\alpha$ is also produced by monocytes, in response to dengue virus infection and/or interaction with $T$ lymphocytes. These cytokine have direct effect on endothelial cells (EC) to induce plasma leakage (bottom right). IFN- $\gamma$ activates monocytes to enhance the activation the expression of MHC molecules and Fc $\gamma R$ and the production of TNF- $\alpha$. IL-2 facilitates $T$ lymphocytes proliferation. The complement cascade is activated by virus-antibody complexes as well as several cytokines to release C3a and C5a, which also have direct effect on vascular permeability. ${ }^{14}$

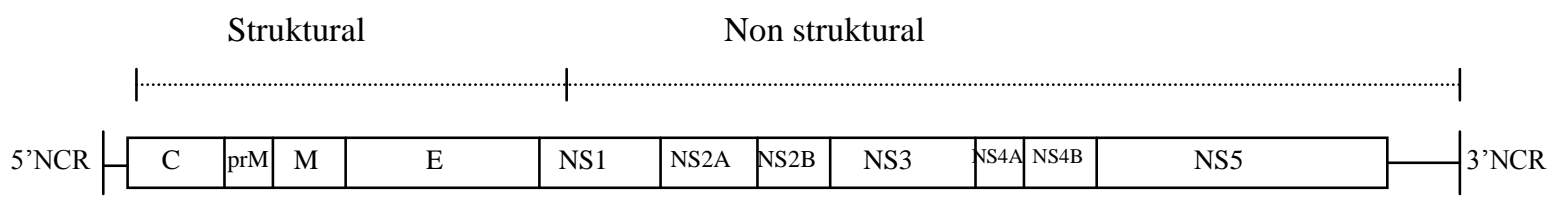

Figure 2. Genome structure and organization of viral protein 


\section{Summary}

The phylogenetic data together with the epidemiological observation, suggest that genetic differences among (and within) the subtype may result in differences in virus virulence and/or epidemic potential. The amino acid substitution within the coding region, which may effect antigenicity or cell attachment, and nucleotide changes within the NTRs, affecting secondary structure and thereby decreases replication, may be the viral determinant of severe dengue in humans. Virus virulence characteristics have been suggested to be due to the synergistic effect of various genomic loci and it is possible that dengue pathogenesis is the result of cohesive activity of the particular sites, in addition to host immunologic factors. Additional research on the biology representatives genotype would help to identity region of dengue which contribute to virulence and also increase understanding of the pathogenesis of a dengue virus infection and eventually aid in its treatment and prevention. Due to Southeast Asia is a probable source of virulent variants to other continents, it is therefore important to have a better understanding of the molecular evolution of dengue virus SE Asian genotype.

\section{REFERENCES}

1. Gubler DJ. Dengue and Dengue Hemorrhagic Fever. Clin Micr Rev 1998; 11(3) : 480-96.

2. Halstead SB. Pathogenesis of dengue: challenges to molecular biology. Science 1988; 230: 476-81.

3. Messer WB, Gubler DJ, Haris E, Sivanathan K, de Silva AM. Emergence and global spread of a dengue serotype 3, subtype III virus. Emerg Infect Dis 2003; 9(7) : 800-9.

4. Pandey BD, Iragashi A. Severity related molecular differences among nineteen strains of dengue type 2 viruses. Microbiol Immunol 2000; 44(3) : 179-88.

5. Leitmeyer KC, Vaughn DW, Watt DM, Salas R, De Chacon IV, Ramos C et al. Dengue Virus Structural Differences That Correlate with Pathogenesis. J Virol 1999; 73(6): 4738-47.

6. Vaughn DW, Green S, Kalayanarooj S, Ennis BI, Nimmannitya S, Suntayakorn S, et al. Dengue viremia titer, antibody response pattern, and virus serotype correlate with disease severity. J Infect Dis 2000; 181: 2-9.

7. Mady BJ, Erbe DV, Kurane I, Fanger MW, Ennis FA. Antibody-dependent enhancement of dengue virus infection. J Immunol 1991; 144:183-8.

8. Rothman AL. Viral pathogenesis of dengue infection. In: Gubler DJ, Kuno G. Dengue and dengue hemorrhagic fever. CAB International. 1997.
9. Bosch I, Xhaja K, Estevez L, Raines G, Melichar H, Warke RV MV, et al. Increased production of intrleukin-8 in primary human monocytes and human epithelial and endhotelial cell lines after dengue virus challenge. J Virol. 2002; 76(11) : 5588-97.

10. Chaturvedi UC, Agarwal R, Elbishbishi EA, Mustafa AS. Cytokine cascade in dengue hemorrhagic fever: implications for pathogenesis. FEMS Immuno Med Microbiol 2000; $28: 183-8$.

11. Diamond MS, Edgil D, Roberts TG, Lu B, Harris E. Infection of human cells by dengue virus is modulated by different cell type and viral strains. J Virol 2000; 74(17) : 7814-23.

12. Rico-Hesse R, Harison L, Salas R, Tovar D, Nisalak A, Ramos C, et al. Origin of dengue type 2 viruses associated with increased pathogenicity in the Americas. Virology. 1997; 230:244-51.

13. Watts DM, Porter KM, Putvatana P, Vasquez B, Calampa $\mathrm{C}$, Hayes CG, et al. Failure of secondary infection with American genotype dengue 2 to cause dengue hemorrhagic fever. Lancet. 1999; 354: 1431-4.

14. Rothman AL, Ennis FA. Immunopathogenesis of dengue hemorrhagic fever. Virology. 1999; 257: 1-6.

15. Rosen L. The pathogenesis of dengue haemorrhagic fever, a critical appraisal of current hypotheses. South Afr Med J : 1986; (Suppl Oct 11): 40-2.

16. Chungue E, Deubel V, Cassar O, Laille M, Martin PMV. Molecular epidemiology of dengue 3 strains isolated from patients with mild or severe form of dengue fever in French Polynesia. J Gen Virol 1993; 74: 2765-70.

17. Kobayashi N, Thayan R, Sugimoto C, Oda K, Saat Z, Viyayamalar B, et al. Am J Trop Med Hyg. 1999; 60(6):904-9.

18. Chambers TJ, Hahn CS, Galler R, Rice M. Flavivirus genome organization, expression, and replication. Annu Rev Microbiol. 1990; 44:649-88.

19. Rico-Hesse R. Molecular evolution and distribution of dengue viruses type 1 and 2 in nature. Virology. 1990; 174:479-93.

20. Lanciotti RS, Lewis JG, Gubler DJ, Trent DW. Molecular evolution and epidemiology of dengue- 3 viruses. J Gen Virol. 1994; 75: 65-75.

21. Mangada MNM, Igarashi A. Molecular and in vitro analysis of eight dengue type 2 viruses isolated from patients exhibiting different disease seveties. Virology. 1998; 244 : 458-66.

22. Cologna R, Rico-Hesse R. American genotype structures decrease dengue virus output from human monocytes and dendritic cells. J Virol. 2003; 77(7):3929-38.

23. Blok J, Gibbs AJ, McWilliam SM, Vitarana UT. NS1 gene suquences from eight dengue-2 viruses ang their evolutionary relationships with other dengue-2 viruses. Arc Virol. 1991; 118: 209-23.

24. Kinney RM, Butrapet S, Chang GJ, Tsuchiya KR, Roehrig JT, Bhamarapravati N, Gubler DJ. Construction of infectious cDNA clones for dengue 2 virus; strain 16681 and its attenuated vaccine derivative, strain PDK53. Virology. 1997; 230:300-8. 